\title{
SYSTEMATIC STUDIES OF BORNEAN ZINGIBERACEAE V. ZINGIBEROIDEAE OF LAMBIR HILLS, SARAWAK
}

\author{
SHOKO SAKAI $^{1} \&$ HIDETOSHI NAGAMASU ${ }^{2}$
}

\begin{abstract}
SUMMARY
This paper reports the subfamily Zingiberoideae (Zingiberaceae) of Lambir Hills National Park, Sarawak, Malaysia. Twelve species representing Boesenbergia, Globba, and Zingiber are recorded. Systematic and ecological notes are provided, and the key to the Bornean species of Boesenbergia is updated. Four species, B. flabellata, B. ischnosiphon, B. lambirensis, and B. lysichitoides, and one variety, $Z$. longipedunculatum var. lambirense are described as new to science. The lectotype of B. grandifolia is designated. In addition, new combinations of Scaphochlamys and Haplochorema are reported.
\end{abstract}

Key words: Zingiberaceae, Borneo, Sarawak, Lambir.

\section{INTRODUCTION}

This paper reports the Zingiberoideae (sensu Kress et al., 2002) (Zingiberaceae) of Lambir Hills National Park, Sarawak, Malaysia. Together with the first and fourth paper of this series (Sakai \& Nagamasu, 1998, 2003) it completes the whole ginger flora of the park. Among genera of Zingiberoideae, three genera, Boesenbergia Kuntze, Globba L. and Zingiber Mill. occur in the park. Systematic notes and lectotypification are also made on B. grandifolia (Valeton) Merr., and new combinations of Scaphochlamys Baker and Haplochorema K. Schum. are reported.

The species are listed in the following order:

from Lambir other species discussed

\begin{tabular}{lll}
\hline $\begin{array}{l}\text { Boesenbergia } \\
\text { Globba }\end{array}$ & $7 \mathrm{spp}$. & $1 \mathrm{sp}$. \\
Haplochorema & $1 \mathrm{sp}$. & $1 \mathrm{sp}$. \\
$\begin{array}{l}\text { Scaphochlamys } \\
\text { Zingiber }\end{array}$ & & $1 \mathrm{sp}$. \\
\hline
\end{tabular}

BOESENBERGIA Kuntze

Sakai \& Nagamasu (in press) reported two types of inflorescence structure in the genus: distichous and one-sided spiral. In all of Zingiberaceae, the one-sided spiral

1) Center for Ecological Research, Kyoto University, Otsu 520-2113, Japan; e-mail: shoko@ecology.kyoto-u.ac.jp.

2) The Kyoto University Museum, Kyoto University, Sakyo, Kyoto 606-8501, Japan. 
inflorescence is only found in the genus Boesenbergia, and all species from Lambir Hills have inflorescences of this type. For both types, flowers open from apex to base in the inflorescence. This mode of flowering is elsewhere in the family only known in the closely related Haplochorema and the probably more distantly related Caulokaempferia Larsen (Smith, 1987).

An important character to identify species, first commented by Valeton (1918), is anther dehiscence patterns. Thecae of some species open by terminal pores, but in others thecae dehisce throughout their length. Smith (1987) described that these pores are not "true pores" in most species, because usually slits are present on the lateral surface of each theca nearest to the style. However, at least in some species there is no slit on the inner face, as observed in B. flabellata (described below). All Lambir species have anthers dehiscing by pores, except $B$. ischnosiphon with thecae dehiscing about half of their length.

Descriptions of mature fruits and seeds of Bornean Boesenbergia are limited; only found in Poulsen (1993; B. urceoligena) and Cowley (1998; B. jangarunii). We describe mature fruits and seeds of $B$. ischnosiphon and B. lambirensis below. Seeds of the four species have a deeply laciniate aril as described for the Malay Peninsular species by Holttum (1950). They may be dispersed by ants as found in Bornean Globba (Pfeiffer et al., 2004). Holttum (1950) also mentioned the thin wall of the capsule, but the wall of $B$. ischnosiphon is not very thin, and does not agree with the other two Bornean species, $B$. lambirensis and B. jangarunii, or peninsular species, while the character is not described for B. urceoligena.

All species observed by Sakai et al. (1999), B. hirta, B. ischnosiphon, B. lambirensis, are pollinated by halictid bees. Most species of the genus seem to flower with little seasonality or synchrony (Sakai, 2000; S. Sakai, pers. obs.).

\section{Boesenbergia flabellata S. Sakai \& Nagam., spec. nov. - Fig. 1, 2a, b}

Haec species nova B. oligospermae (K. Schum.) R.M. Sm. caulibus multifoliatis, floribus flavis et antherae thecae poris dehiscentibus similis, sed differt inflorescentia ca. 16-flora (ca. 6-flora in B. oligosperma) et foliis linearibus, 16-22 cm longis, flabellatis. - Typus: S. Sakai 399 (holo KYO; iso SAR), Sarawak, Lambir Hills, along Pantu Trail, on the slope, near Nibong waterfall, locally abundant, flower pale yellow, denser on the centre, 26.12.1998.

Erect herb c. $30 \mathrm{~cm}$ tall, with c. 12 leaves per shoot (when fertile), flabellate (Fig. $2 \mathrm{a}$ ); bladeless sheath 0 ; lamina (13-)16-22(-25) by $1.2-2.6 \mathrm{~cm}$, papery, glabrous throughout, apex acute, base unequally cuneate; petiole $5-30 \mathrm{~mm}$ long, glabrous; sheath $5.5-10 \mathrm{~cm}$ long, papery, leaf sheath with inflorescence usually c. $2 \mathrm{~cm}$ shorter than sterile ones next to the fertile one, glabrous throughout, margin membranous; ligule to $13 \mathrm{~mm}$ long, membranous, 2-lobed to the base, triangular, continuing into the membranous margin of the leaf sheath, glabrous. Inflorescence terminal, with c. 16 flowers, bracts arranged in a one-sided spiral (Fig. 1a); outermost fertile bract $4.5-6.5$ by $1.4-2 \mathrm{~cm}$, papery, oblanceolate, glabrous on both surfaces, margin membranous; inner ones papery to membranous, slightly shorter and much narrower, innermost bracts 35 by $3.5 \mathrm{~mm}$ (except sterile or remnant bracts at the top), glabrous; bracteole $25-35$ by $3.5-5 \mathrm{~mm}$, membranous, linear, open to the base. Flower borne singly, yellow (Fig. 2b); 

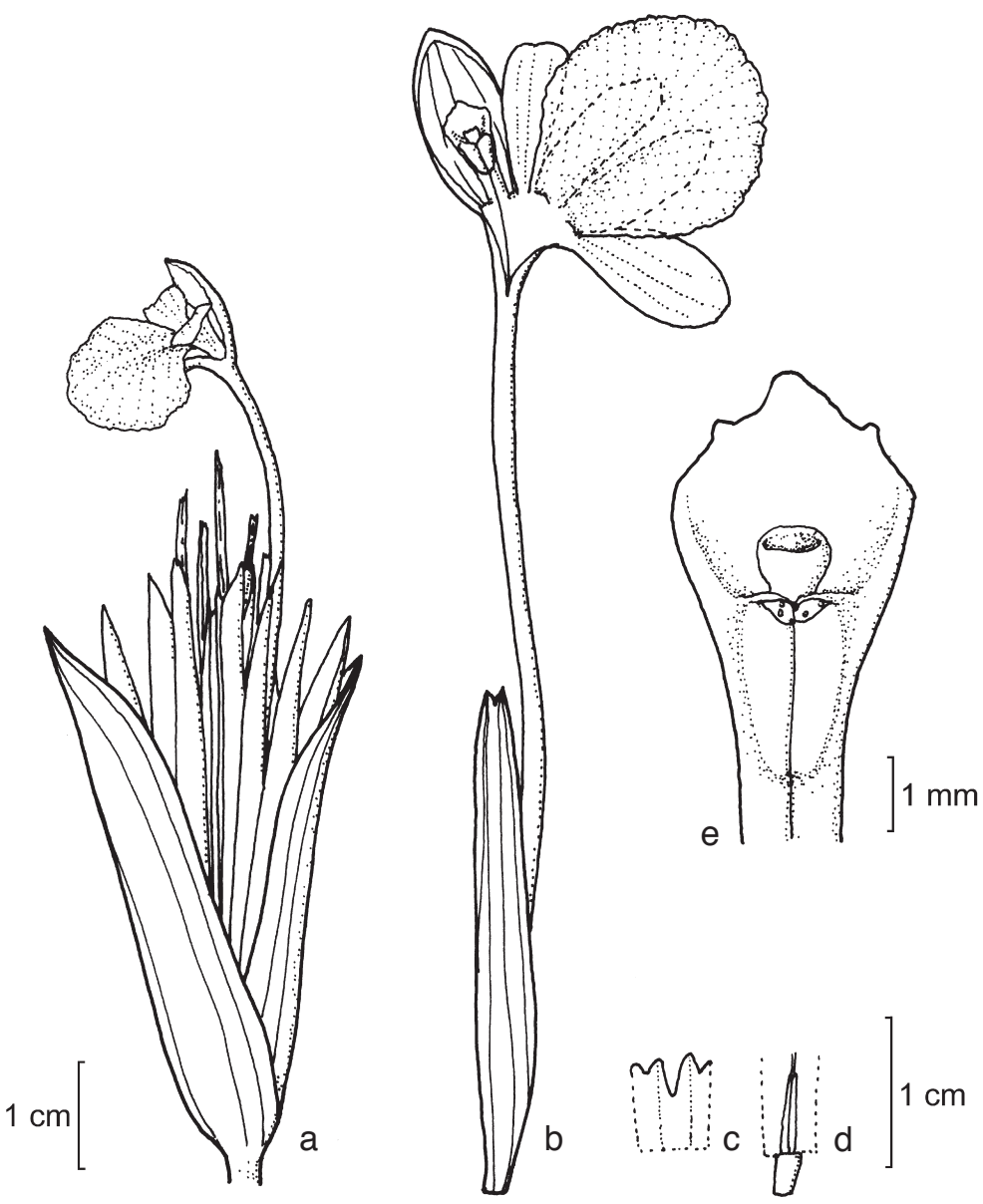

Fig. 1. Boesenbergia flabellata S. Sakai \& Nagam. a. Inflorescence with an open flower; b. bracteole and flower, with dissection on uppermost part of corolla tube; c. calyx; d. ovary and epigynous gland; e. stigma and stamen (from spirit material of Nagamasu 6728).

calyx membranous, c. $6 \mathrm{~mm}$ long, tubular, rarely fissured to the base, glabrous, apex unequally 2- or 3-lobed (Fig. 1c); corolla tube c. $55 \mathrm{~mm}$ long, glabrous; corolla lobes membranous, elliptic, glabrous on both surfaces, dorsal lobe c. 15 by $6 \mathrm{~mm}$, laterals c. 13 by $4 \mathrm{~mm}$; lateral staminodes c. 12 by $5 \mathrm{~mm}$, obovate, glabrous on both surfaces; labellum $17-19$ by $15-18 \mathrm{~mm}$, broadly obovate, nearly entire, totally yellow, denser toward the centre, glabrous on both surfaces (Fig. 1b); stamen glabrous throughout; filament c. $2 \mathrm{~mm}$ long; anther c. $3 \mathrm{~mm}$ long, opening by pore without a slit on the inner surface of the thecae but with a very short notch; anther crest c. $3 \mathrm{~mm}$ long, shallowly 3-lobed, the central lobe with somewhat obtuse top (Fig. 1e); stigma cup-shaped without hairs, dorsiventrally flattened, bent abaxially; ovary c. $3 \mathrm{~mm}$ long, glabrous, imperfectly trilocular, with c. 10 ovules, axial placentation; epigynous gland c. $5 \mathrm{~mm}$, in two parts, apex rounded (Fig. 1d). Capsules unknown. 
Distribution - Borneo, Sarawak, Lambir Hills.

Habitat \& Ecology - The species is locally abundant near small streams along the trails to Bt. Pantu and Bt. Lambir.

Etymology - The epithet 'flabellata' refers to the flabellate arrangement of leaves on a shoot.

Note - Though the fan-like shoot with linear leaves resembles $B$. burttiana, the anther thecae of $B$. flabellata open by terminal pores without slits, is clearly separating the two species. Boesenbergia flabellata is further distinguished from B. burttiana by the yellow flower rather than white with some red and yellow on the labellum.

Other specimens examined:

SARAWAK. Lambir Hills: S. Sakai 101 (KYO), near a small stream, 08.10.1994; Nagamasu 6728 (KYO, SAR), along Pantu trail, above Nibong waterfall, 27.02.1999; Burtt 11582 (E), S. Liam Libau, locally common, 22.09.1978.

\section{Boesenbergia hirta (Ridl.) Merr. - Fig. 2c-e}

Gastrochilus hirtus Ridl. (1909) 57. — Boesenbergia hirta (Ridl.) Merr. (1921) 122; R.M. Sm. (1987) 227. - Type: Hewitt 20 (SING), Sarawak, 2nd Division, Bukit Tiang Laju, flowers white, lip with some red centrally.

Habitat \& Ecology - The species occurs on the floors of wet and relatively open forests, often with other Boesenbergia such as B. lambirense and B. ischnosiphon. It does not form a large clump. The species has white flowers with some red and yellow on the central part of the labellum as many other congeners. Flowers are pollinated by halictid bees (Sakai et al., 1999, cited as B. aff. variegata).

Notes - According to Smith (1987) no recent collection of the species had been seen. The type material contains no flowers on the type sheet and the original description by Ridley (1909: 57) is incomplete. Although the description says the lamina is glabrous, the type material has sparse long hairs on the upper surface and somewhat denser on the lower surface. The material from Lambir is similar to the type specimen in many characters such as 2- or 3-leaved shoots, obovate leaves with attenuate base of similar size, cuspidate and pubescent bracts, while ligules are shorter in Lambir plants (up to $2 \mathrm{~cm}$, Fig. $2 \mathrm{c}$ ) than in the type $(2-4 \mathrm{~cm})$. On the other hand, floral sizes of the Lambir plants are somewhat different from the description in having longer and glabrous corolla lobes $(10-12 \mathrm{~mm})$ rather than hairy ones of $6 \mathrm{~mm}(1 / 4 \mathrm{inch})$ described by Ridley (1909: 57). In Lambir plants anthers open by pores, but there is no description about the character in the original description. We tentatively identify the material from Lambir as $B$. hirta since no other materials of the species from the type locality are available at the moment.

In the field, the species is recognized by thick dark green leaves with a central line of much lighter green (Fig. 2d) often with the purplish or reddish lower surface (Fig. 2e). Variegation may be quickly lost in dried specimens, and the character is neither discernible in the type material nor in some of the collections from Lambir Hills. There are no notes on colour on lamina in the original description or on the specimen label.

Other specimens examined:

SARAWAK. Lambir Hills: S. Sakai 44 (KYO), in mixed dipterocarp forest, flower white, lower surface of the leaf purple upper dark green, 16.06.1994; S. Sakai 173 (KYO), flowers white, yellow 
on the centre of the lip and red at the base, 13.03.1995; S. Sakai 397 (KYO), along the main trail to the third waterfall, 1-3 leaves per shoot, leaves dark green on the upper surface, lower red or purplish red, flower creamy white with central yellow line, 25.12.1998; S. Sakai 1012 (KYO, SAR), 3rd waterfall, several-leaved, lamina dark green with some silver on the centre above, tinged red purple below, 22.07.2004.

3. Boesenbergia ischnosiphon S. Sakai \& Nagam., spec. nov. - Fig. 2f-i, 3

Boesenbergiae cordatae R.M. Sm. caulibus fertilibus unifoliatis et petiolis longis similis, sed laminis basi breviter attenuatis non cordatis et corollae tubo multo longiore differt. - Typus: Nagamasu 6202 (holo KYO), Lambir Hills, flower white, labellum white with yellow blotch on the centre and with red patches near the base, 07.09.1996.

Erect herb to $40 \mathrm{~cm}$ tall, fertile shoots single-leaved (Fig. 2f), rarely two; bladeless sheaths few, to $10 \mathrm{~cm}$ long, $10 \mathrm{~mm}$ wide, papery, glabrous, margin membranous; lamina coriaceous, $16-20$ by $4-5 \mathrm{~cm}$, lanceolate to oblanceolate, glabrous on both surfaces, apex obtuse or shortly acuminate, base shortly attenuate; petiole 7-13 cm long; ligule c. $1.7 \mathrm{~cm}$, membranous, bilobed to the base, glabrous. Inflorescence terminal, sessile, with 4-6 flowers (Fig. 3a); bracts arranged in a one-sided spiral, membranous, glabrous, outermost one c. $5.5 \mathrm{~cm}$ long, sterile, linear, boat-shaped, inner bract shorter and narrower; bracteole c. $2.3 \mathrm{~cm}$ long, membranous, open to the base, linear, glabrous. Flower borne singly, white; calyx $8-15 \mathrm{~mm}$ long, membranous, tubular, unilaterally fissured to half of the length, glabrous, apex 2-toothed (Fig. 3e); corolla tube c. $9 \mathrm{~cm}$ long, glabrous; corolla lobes membranous, elliptic, glabrous, dorsal lobe c. 19 by $5 \mathrm{~mm}$, laterals c. 15 by $4 \mathrm{~mm}$; lateral staminodes c. 12 by $4 \mathrm{~mm}$, obovate, glabrous on both surfaces; labellum c. 19 by $12 \mathrm{~mm}$, obovate, nearly entire, white with yellow blotch on the centre and with red patches near the base, glabrous on both surfaces (Fig. 3b); stamen glabrous throughout; filament c. $3.5 \mathrm{~mm}$ long; anther c. $5 \mathrm{~mm}$ long, thecae dehisce $1 / 2$ to $2 / 3$ from apex on internal sides; anther crest c. $1 \mathrm{~mm}$ long, truncate; stigma cup-shaped without hairs, dorsiventrally flattened, erect or bent abaxially (Fig. 3c); ovary c. $5 \mathrm{~mm}$ long, glabrous (Fig. 3e), imperfectly trilocular, with c. 10 ovules, axial placentation; epigynous gland c. $5 \mathrm{~mm}$, in two parts, apex pointed. Capsules c. 30 by $5 \mathrm{~mm}$ excluding the remaining calyx base, ellipsoid, glabrous, white tinged red, single-seeded (Fig. 2h); wall of the fruit is soft, and rolled up when dehisced (Fig. 2i); seeds c. 12 by $4 \mathrm{~mm}$, obovoid with laciniate aril covering half of the length of the seed (Fig. 3d).

Distribution - Borneo, Sarawak, Lambir Hills.

Habitat \& Ecology - Boesenbergia ischnosiphon often forms a dense clump with dozens of single-leaved shoots, on floors of wet and relatively open forests. Flowers are pollinated by halictid bees (Sakai et al., 1999, cited as B. gracilipes).

Etymology - The epithet 'ischnosiphon' refers to the plant's long and thin corolla tube.

Notes - Boesenbergia ischnosiphon is characterized by single-leaved shoots with a long petiole and an elliptic lamina. There are quite a few specimens from Borneo with these characteristics, but they are not identical. Burtt 8281 (E) from Mulu is different from Lambir material in having pubescent anthers dehiscing throughout their length, as well as some pubescence in the upper part of the bracts, sheaths and ligules. P.C. Boyce 272 and 297 (K) from Brunei have much shorter corolla tubes (c. $5.5 \mathrm{~cm}$ ) 

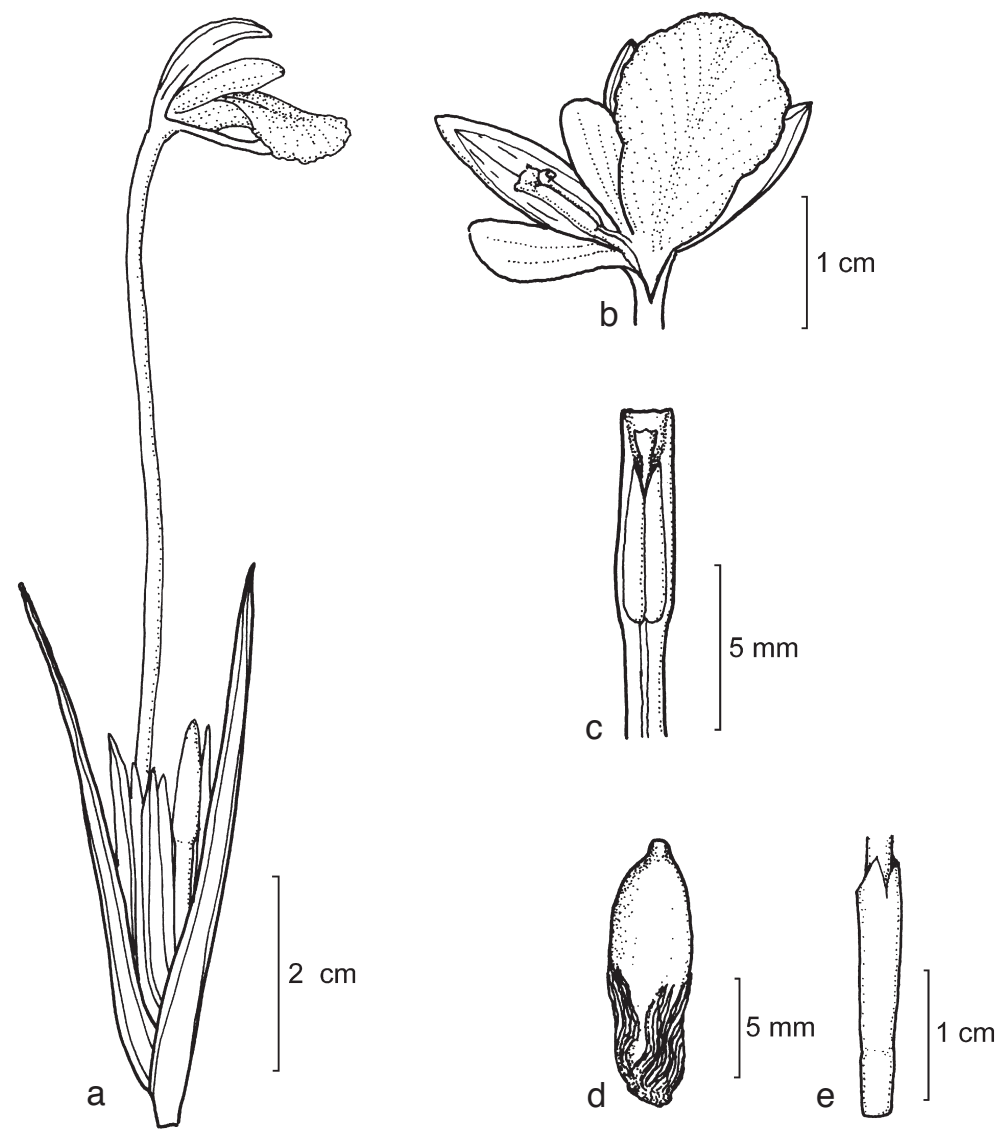

Fig. 3. Boesenbergia ischnosiphon S. Sakai \& Nagam. a. Inflorescence with an open flower; b. upper part of corolla with dissection on uppermost part of corolla tube; c. stigma and stamen; d. seed with laciniate aril; e. ovary and calyx (a-c, e: spirit material of S. Sakai 79; d: spirit material of S. Sakai $1001)$.

than the material from Lambir $($ c. $9 \mathrm{~cm})$. More collections from Borneo, including pickled flowers, are needed to examine the variation within species.

The collection Burtt 8281, mentioned above, was initially misidentified as Boesenbergia gracilipes (K. Schum.) R.M. Sm. by Smith (1987). Whereas Burtt 8281 is still in concordance with the description of Boesenbergia, a closer inspection of the inflorescence of the type of B. gracilipes indicates that this should be transferred to Scaphochlamys (see p. 110).

The description of the seed above is based on S. Sakai 1001 consisting of a singleseeded fruit. The day after collecting, the fruit dehisced automatically (Fig. 2h, i), and the seed inside was exposed. The wall of the fruit was rather thick and soft, and different from other species known so far which have thin-walled capsules (Holttum, 1950; Smith, 1987; Cowley, 1998). However, it is uncertain if the fruit was already mature or fruits of $B$. ischnosiphon always have one seed only. 

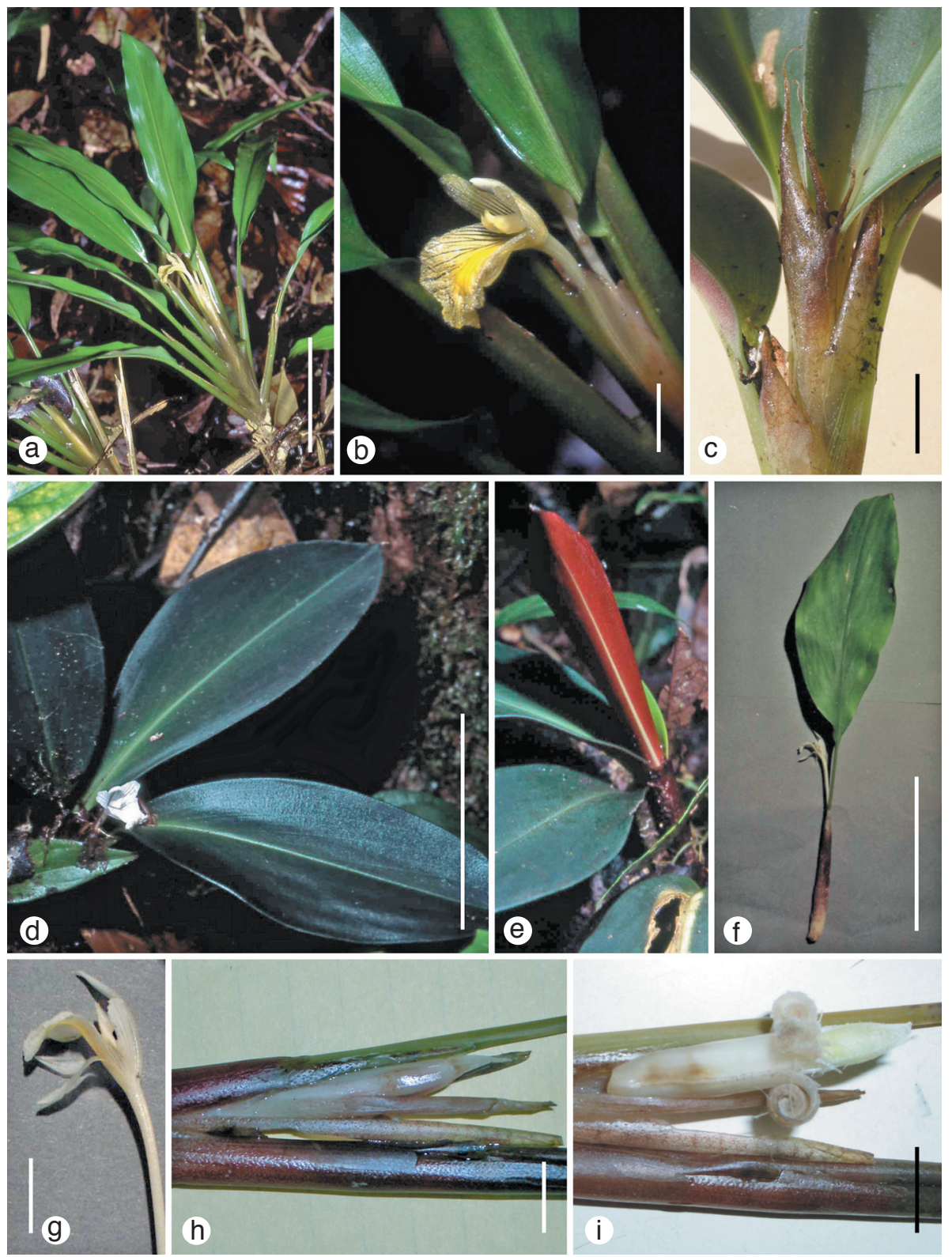

Fig. 2. a, b: Boesenbergia flabellata S. Sakai \& Nagam. a. Habit showing fan-like arrangement of leaves on shoot; b. flower. - c-e: B. hirta (Ridl.) Merr. c. Long cuspidate ligule; d. habit showing leaves dark green with a central line of light green; e. red lower surface of leaf. $-\mathrm{f}-\mathrm{i}$ : B. ischnosiphon S. Sakai \& Nagam. f. Habit; g. flower; h. fruits on inflorescence; i. dehiscing fruit and seed inside (a, b: S. Sakai 399; c: S. Sakai 1012; d, e: S. Sakai 397; f, g: S. Sakai 79; h, i: S. Sakai 1001). — Scale bars: $\mathrm{a}, \mathrm{d}-\mathrm{f}=10 \mathrm{~cm} ; \mathrm{b}, \mathrm{c}, \mathrm{g}-\mathrm{i}=1 \mathrm{~cm}$. 
Other specimens examined:

SARAWAK. Lambir Hills: S. Sakai 79 (KYO), on the slope near the second waterfall, 18.08.1994; S. Sakai 81 (KYO), near the second tree tower, 18.08.1994; M.N. Tamura \& A. Takano S-0043 (HYO, OSA), 21.11.1996; M.N. Tamura \& A. Takano S-0075 (HYO, OSA), small stream near HQ, 30.11.1996; M.N. Tamura \& A. Takano S-0104 (HYO, OSA), under mixed dipterocarp forest, red yellow podzolic soil, 05.12.1996; S. Sakai 1001 (KYO, SAR), small stream near headquarter, flower white with yellow on centre of lip, red at throat, immature fruit enclosed in leaf sheath, 16.04.2004.

\section{Boesenbergia lambirensis S. Sakai \& Nagam., spec. nov. - Fig. 4, 5a-d}

Species nova B. grandifoliae (Valeton) Merr. caulibus unifoliatis et antherae thecae poris dehiscentibus similis, sed a qua foliis multo minoribus ellipticis basi attenuatis et partibus vegetativis densius pubescentibus differt. - Typus: Burtt \& Woods 2430 (holo E; iso SAR), Sarawak, Lambir Hills, flowers white, deep yellow in centre of lip, with somewhat paler line running to base with reddish pink line, 06.08.1962.

Erect herb c. $30 \mathrm{~cm}$ tall, fertile shoot usually with a single leaf (Fig. 5a); bladeless sheaths few, to 11 by $2.3 \mathrm{~cm}$, purplish, oblong to obovate, tubular at the base, striate, with thick hairs outside, almost glabrous to sparsely hairy inside, margin membranous, fragile and usually broken; lamina of fertile shoots $17-26$ by $7-12 \mathrm{~cm}$, papery, obovate, unequal, upper surface glabrous or with sparse long appressed hairs, lower with denser hairs especially around midrib, which may easily fall off, apex obtuse to acute, base shortly attenuate into the petiole; ligule to $2.5 \mathrm{~cm}$, papery to membranous, linear but often broken off; petiole to $4 \mathrm{~cm}$, slightly winged, densely hairy. Inflorescence terminal, borne at the middle of the sheath, almost sessile, subtended by a few sterile bracts (Fig. $4 \mathrm{~g}$ ); sterile bracts c. 6 by $2 \mathrm{~cm}$, coriaceous to papery, ovate, pubescent outside, almost glabrous inside, the outermost bract not well-exceeding the fertile bracts; fertile bracts arranged in a one-sided spiral; fertile bract to 3.5 by $1 \mathrm{~cm}$ outermost, linear lanceolate, pubescent outside, glabrous inside, apex obtuse and acuminate, ciliate; inner bracts to 40 by $8 \mathrm{~mm}$, linear, pubescent outside, glabrous inside, apex ciliate (Fig. 4d); bracteole 20-25 mm long, c. $8 \mathrm{~mm}$ wide, membranous, boat-shaped, open to the base, apex slightly acuminate, sparsely hairy, denser toward apex outside, glabrous inside (Fig. 4e); 15-20 flowers in the inflorescence, borne singly per bract, white (Fig. 4f, 5b); calyx c. $9 \mathrm{~mm}$, membranous, tubular, unilaterally fissured for half the length, apex unequally 3-toothed, with long soft hairs outside, glabrous inside; corolla tube 28-30 $\mathrm{mm}$ long, densely hairy outside, glabrous inside except the pubescent throat; corolla lobes membranous, elliptic, glabrous on both surfaces, dorsal lobe 10-14 by 4-6 mm, laterals $9-13$ by $3-4.5 \mathrm{~mm}$; lateral staminodes $9-12$ by $4.5-5 \mathrm{~mm}$, obovate, glabrous on both surfaces; labellum c. $15-19$ by $10-15 \mathrm{~mm}$, broadly elliptic, almost entire, white with yellow central line with red patches near the base, glabrous on both surfaces (Fig. 4f); stamen white; filament c. $1.5 \mathrm{~mm}$ long, more or less pubescent; anther c. 4 $\mathrm{mm}$ long, dehiscing by apical pores from which a slit runs down on the internal sides of each theca; anther crest c. $4.5 \mathrm{~mm}$ long, boat-shaped, with entire or 3-lobed apex, glabrous; stigma cup-shaped without hairs, dorsiventrally flattened, bent abaxially (Fig. 4c); ovary c. 2 by $1.5 \mathrm{~mm}$, almost glabrous on lower half, densely pubescent on the upper, imperfectly trilocular, with c. 6 ovules, axial placentation; epigynous gland c. $5 \mathrm{~mm}$, in two parts, apex blunt, glabrous. Capsules $16-18$ by $5-8 \mathrm{~mm}$, ellipsoid, 

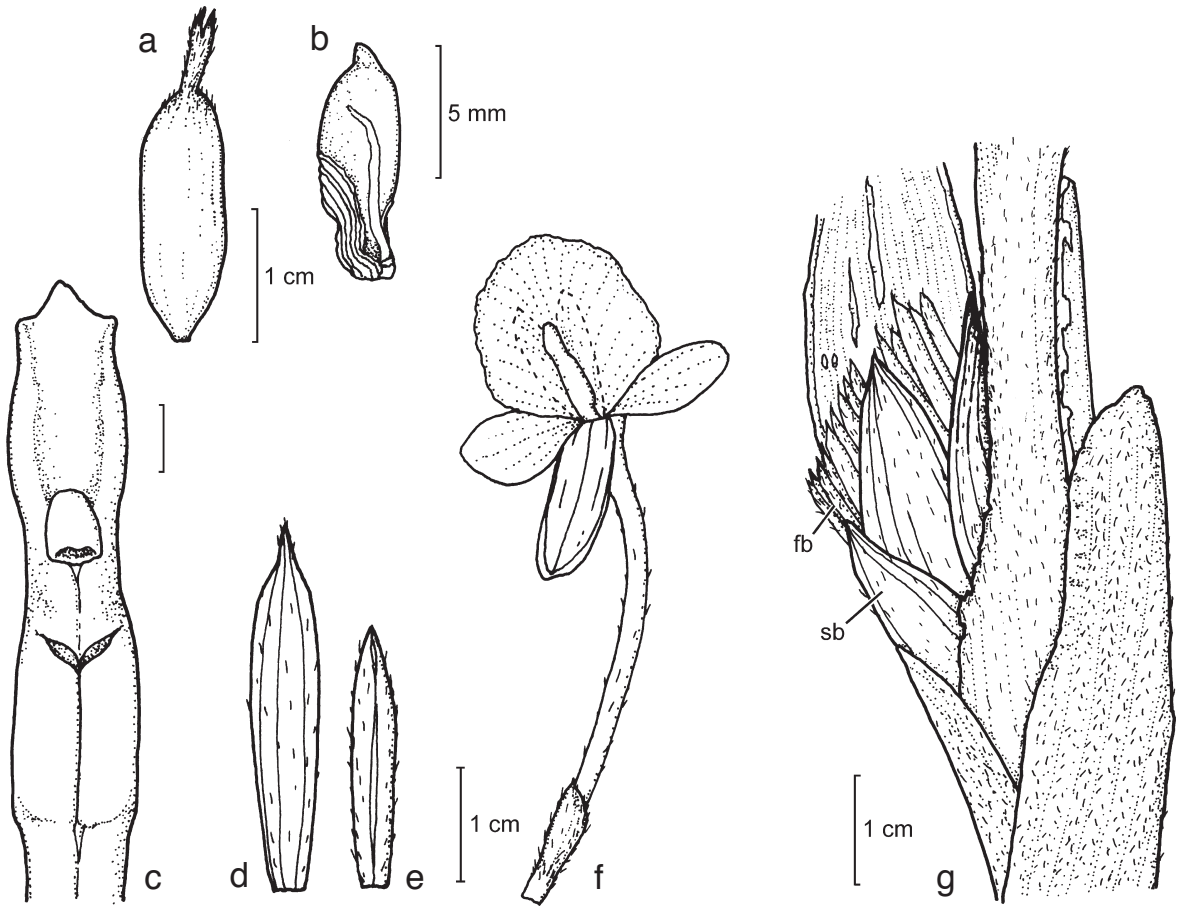

Fig. 4. Boesenbergia lambirensis S. Sakai \& Nagam. a. Fruit; b, seed; c. stamen and stigma; d. bract; e. bracteole; f. flower; $g$. inflorescence subtended by sterile bracts and leaf sheath, $\mathrm{sb}=$ sterile bract, $\mathrm{fb}=$ fertile bract (from spirit material of S. Sakai 1014).

white, with persistent calyx, with 2-7 seeds (Fig. 4a, 5c); seed c. 8 by $3 \mathrm{~mm}$, ellipsoid, thin-walled, light brown, mounted with laciniate aril which shrink when preserved in alcohol (Fig. 4b, 5d).

Distribution - Borneo, Sarawak, Lambir Hills.

Habitat \& Ecology - Most fertile shoots of B. lambirensis bear only one leaf; occasionally none. The first author found a similar plant, but with a several-leaved shoot (S. Sakai 1013, KYO), at the third waterfall of Lambir Hills where B. lambirensis and $B$. hirta grow in close proximity. Since young leaves of the plant had some purple on the lower surface similar to $B$. hirta, the plant might be a hybrid.

The species often form a loose clump at relatively open and wet sites. It flowers sporadically without particular flowering season (Sakai, 2000), and is pollinated by halictid bees (Sakai et al., 1999). In both publications, the species is cited as B. grandifolia. The fruit of B. lambirensis has a thin wall. Seeds occasionally germinate while the fruit is still attached to the infructescence but only after it has dehisced.

Note - In Smith (1987) Burtt \& Woods 2430 was identified as B. grandifolia (ut $B$. grandiflora). But the material was quite different from the lectotype (see below) in having much smaller and elliptic leaves $(26 \mathrm{~cm}$ long) rather than huge, obovate leaves (80 cm long, including petiole in B. grandifolia) with attenuate bases. In addition, it 
is rather pubescent with long soft hairs on the lower surface of the lamina and thick hairs on the leaf sheath. See below in B. grandifolia.

Other specimens examined:

SARAWAK. Lambir Hills: S. Sakai 77 (KYO), along the trail to the first waterfall, 16.08.1994; S. Sakai 174 (KYO), valley, flower white, yellow on the centre of the lip and red at the base, 13.03.1995; S. Sakai 1014 (KYO, SAR), the third waterfall, single-leaved, lamina light green, flower white with some red and yellow on the throat, 22.06.2004.

5. Boesenbergia lysichitoides S. Sakai \& Nagam., spec. nov. - Fig. 5e, f, 6

Haec species B. lambirensi S. Sakai \& Nagam. valde similis, sed plantis majoribus, caulibus 2-4-foliatis, bracteis coriaceis sterilibus illas fertiles excedentibus differt. - Typus: S. Sakai 414 (holo KYO; iso SAR), Sarawak, Lambir Hills, Sungai Liku, on the marshy ground, $0.5 \mathrm{~m}$ high, fertile shoots usually 2 -4-leaved, leaves bright green, basal part of midrib on the upper surface dark brown, flower white, labellum white with central yellow line and red on the throat, 28.12.1998.

Perennial herb c. $50 \mathrm{~cm}$ tall (Fig. 5e), fertile shoot 2-4-leaved, rarely single, usually covered with a few bladeless sheaths at the base, especially in young shoots; bladeless sheath to 17 by $3 \mathrm{~cm}$, papery, but usually much shorter, purplish even after it has dried, densely hairy outside, glabrous inside; lamina 40-48 cm long, c. $13 \mathrm{~cm}$ wide, obovate, plain green, purplish towards base and petiole, basal part of midrib on the
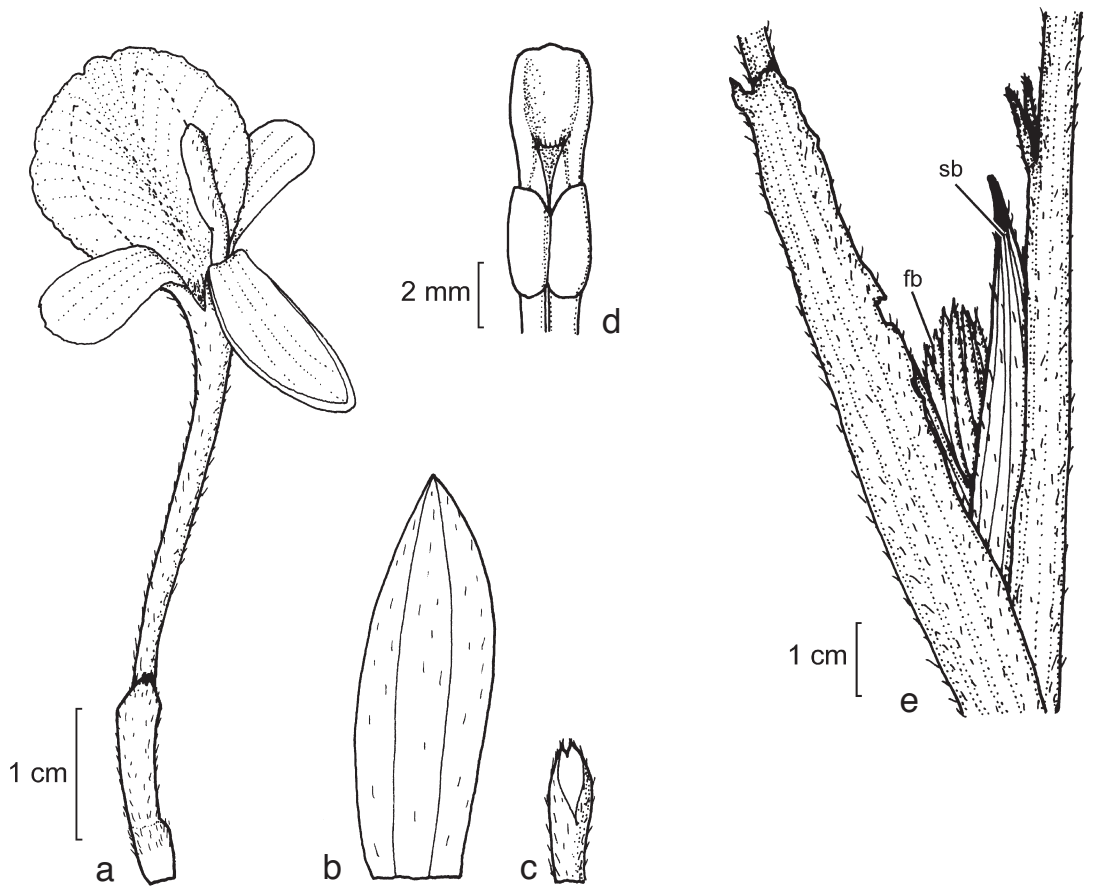

Fig. 6. Boesenbergia lysichitoides S. Sakai \& Nagam. a. Flower with some dissection on uppermost part of corolla tube; b. bracteole; c. calyx; d. stamen and stigma; e. inflorescence on the shoot, sb = sterile bract, $\mathrm{fb}=$ fertile bract (a-d: spirit material of S. Sakai 414; e: dry material of S. Sakai 414). 

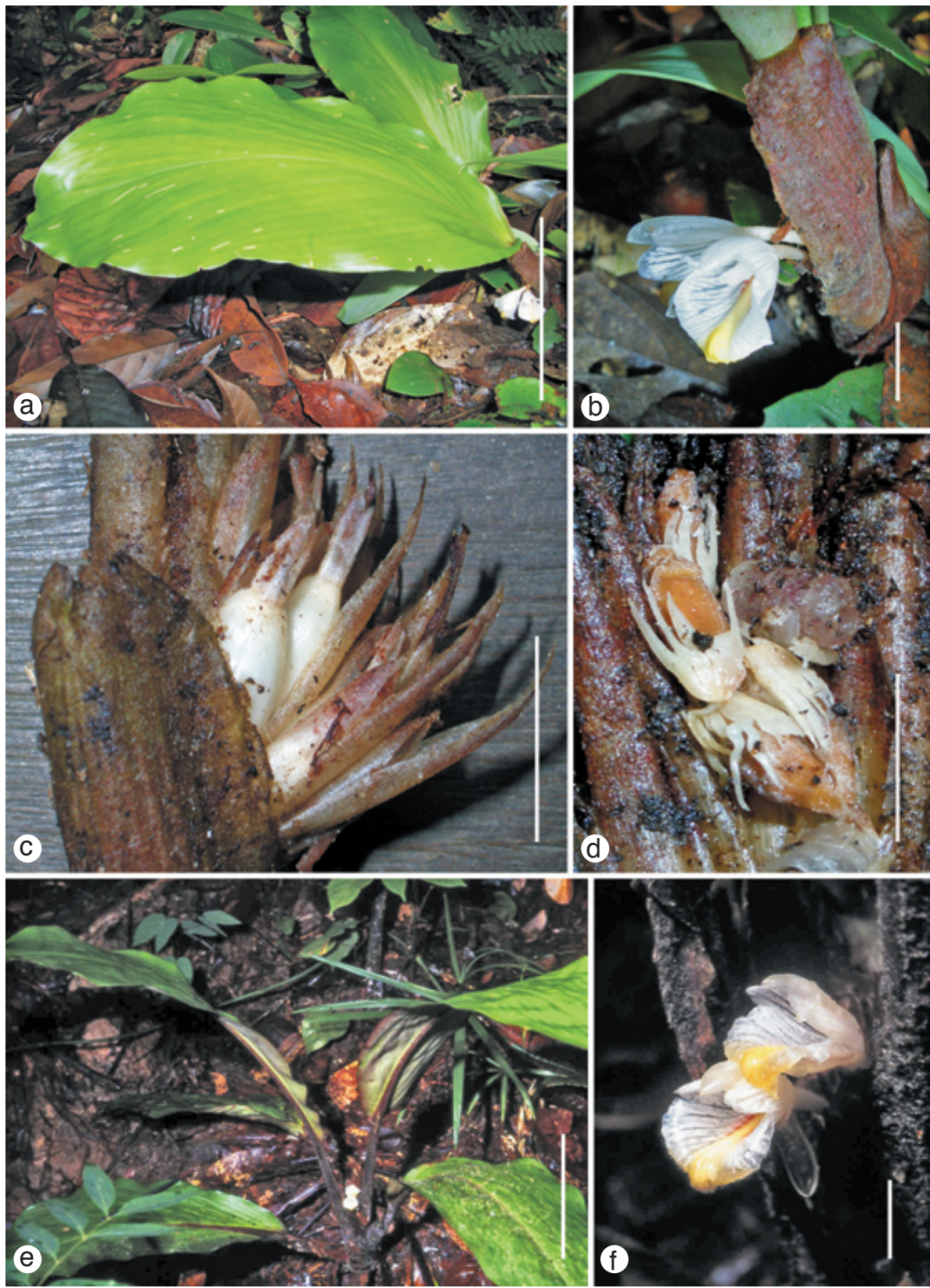

Fig. 5. a-d: Boesenbergia lambirensis S. Sakai \& Nagam. a. Habit; b. flowers; c. fruits on infructescence; d. seeds with white laciniate aril. - e, f: B. lysichitoides S. Sakai \& Nagam. e. Habit; f. flowers (a-d: S. Sakai 1014; e, f: S. Sakai 414). - Scale bars: a, e = $10 \mathrm{~cm} ; \mathrm{b}-\mathrm{d}, \mathrm{f}=1 \mathrm{~cm}$. 
upper surface dark brown, below with long appressed hairs especially on and around midrib, almost glabrous on the upper, hairs getting denser toward base and apex, apex acute or slightly acuminate, base attenuate into thick petiole with groove or winged; petiole to $3 \mathrm{~cm}$ long, densely covered with robust hairs; ligule fragile and short-lasting, to 2 (?) $\mathrm{cm}$ long, probably 2-lobed to the base, densely pubescent outside, almost glabrous inside; sheath densely pubescent, margin membranous. Inflorescence terminal, with c. 20 flowers arranged in a one-sided spiral (Fig. 6e); sterile bract a few, c. 7.5 by $1.3 \mathrm{~cm}$ (outermost), coriaceous, narrowly ovate, apex of the outermost sterile bracts exceeding the fertile bracts by c. $1.5 \mathrm{~cm}$, densely pubescent outside, glabrous inside, apex obtuse and acuminate; fertile bracts $2-3.5 \mathrm{~cm}$ long, to $4 \mathrm{~mm}$ wide, papery to coriaceous, oblong, densely pubescent with long hairs outside, glabrous inside; bracteole c. 3 by $1 \mathrm{~cm}$, lanceolate, softly pubescent outside, glabrous inside, margin membranous, apex acute (Fig. 6b). Flower borne singly, white (Fig. 6a); calyx c. $10 \mathrm{~mm}$, unilaterally fissured for half its length, densely pubescent outside, glabrous inside, apex 2-toothed (Fig. 6c); corolla tube c. $3.8 \mathrm{~cm}$, pubescent outside, glabrous inside except pubescence at the throat; corolla lobes membranous, lanceolate, glabrous, dorsal lobe c. 15 by $6 \mathrm{~mm}$, laterals c. 12 by $4 \mathrm{~mm}$; lateral staminodes c. 9 by $5 \mathrm{~mm}$, oblong to obovate, glabrous; labellum c. 16 by $16 \mathrm{~mm}$, broadly ovate, slightly 3-lobed at the apex, white with a central yellow line with red blotches at the throat, glabrous (Fig. 5f, 6a); stamen $9 \mathrm{~mm}$ long, shortly pubescent; filament c. $2 \mathrm{~mm}$ long, shortly and sparsely pubescent; anther c. $3.5 \mathrm{~mm}$ long, open by pores from which a slit along the internal side of each theca, glabrous; anther crest c. $4 \mathrm{~mm}$, lateral part of the crest swollen to enfold the stigma, glabrous; stigma cup-shaped with apical opening, with sparse hairs around the mouth (Fig. 6d); ovary c. $4.5 \mathrm{~mm}$, probably incompletely trilocular, a few ovules per locule, axial placentation, pubescent only upper half; epigynous gland c. $5 \mathrm{~mm}$, in two parts, linear, apex blunt. Capsules unknown.

Distribution - Borneo, Sarawak, Lambir Hills.

Habitat \& Ecology - The plant is rather abundant on marshy ground of Sg. Liku, Lambir Hills, but has not been collected from other sites.

Etymology - The epithet refers to the vegetative characters and habitat of the species resembling Lysichiton (Araceae).

\section{Boesenbergia parva (Ridl.) Merr.}

Gastrochilus parvus Ridl. (1905) 195. - Boesenbergia parva (Ridl.) Merr. (1921) 122; R.M. Sm. (1987) 230. - Type: Ridley s.n. (SING), cultivated in Singapore, originally from Sarawak, 1st Division, Bidi, 05.1904.

Habitat \& Ecology - The species is abundant along trails to Bt. Pantu and Bt. Lambir.

Note - The specimens collected at swampy lowland sites, S. Sakai 140 (KYO) and S. Sakai 409 (KYO), have longer leaf sheaths and larger flowers, but otherwise are very similar to $B$. parva. To clarify the identity of the plants we need to know the variation within $B$. parva, which has a relatively large distribution in Borneo.

Other specimens examined:

SARAWAK. Lambir Hills: Burtt 11510 (E, SAR), Sungai Liam Libau, flower white, except for yellow centre of lip, 18.9.1978; Ikegami 29 (KYO), on the way to Bt. Lambir, 08.10.1994; S. Sakai 219 
(KYO), along the trail to Bt. Pantu, flower white, with yellow and red centrally on the lip, 21.04.1995; A. Naiki 1208 (KYO), flower white, sandy soil, 5.5.1998; S. Sakai 398 (KYO), 1-4 leaves per shoot, flowers white with central yellow line edged somewhat red, 26.12.1998; S. Sakai 400 (KYO), along Pantu trail, near small stream, 1-4 leaves per shoot, flower white, with central yellow line edged somewhat red, 26.12.1998; S. Sakai 401 (KYO), along Pantu trail, near summit of Bt. Pantu, 1-4 leaves per shoot, upper leaf surface dark green, lower pale green tinged with purple, flower white, with central yellow line edged somewhat red, 26.12.1998; Nagamasu 6733 (KYO), along Pantu trail, 200-250 m altitude, leaf sheath developed, flowers white, the lip white with yellow centre line and with red blotch at the base, 27.02.1999; Nagamasu 6734 (KYO), along Pantu trail, 200-250 m alt., flowers white, the lip white with yellow centre line with/without red blotch the base, 27.02.1999; Nagamasu 6739 (KYO), along trail to the summit of Bt. Lambir, 200-465 m tall, flowers white, the lip yellow at the tip, 28.02.1999.

\section{Boesenbergia grandifolia (Valeton) Merr. - Fig. 7b}

Gastrochilus grandifolius Valeton (1914) 241; (1918) 98. - Boesenbergia grandifolia (Valeton) Merr. (1921) 122. - Type: Nieuwenhuis 939 (lectotype BO, designated here), Borneo, Tebululan-Teputing.

Notes - The original description (Valeton, 1914: 241) did not cite specimens precisely, but mentioned “Borneo, collected by Nieuwenhuis?". Later, Valeton (1918) cited Nieuwenhuis 936 and 939 as the species, which are kept at the Herbarium Bogoriense. The two are from the same locality, the former has a 2-leaved sterile shoot, and the latter a single-leaved shoot with an inflorescence. We selected the latter as the lectotype (Fig. 7b).

Boesenbergia grandifolia is more or less glabrous in the vegetative part. The species is further characterized by large leaves measuring $70-100 \mathrm{~cm}$ including the petiole.

\section{KEY TO BORNEAN BOESENBERGIA \\ (modified from Smith, 1987)}

1a. Creeping herbs; shoots normally single-leaved; inflorescence more or less sessile;

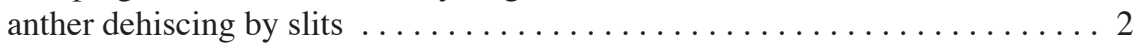

b. Erect herbs; shoots with one to many leaves; inflorescence sessile or long pedunculate; anther dehiscing by slits or pores $\ldots \ldots \ldots \ldots \ldots \ldots \ldots \ldots \ldots \ldots \ldots \ldots \ldots$

2a. Leaves more or less circular, obtuse or obscurely emarginate at apex . . . . . .

B. orbiculata

b. Leaves elliptic or lanceolate, acute at apex ............... 3

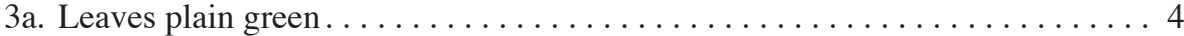

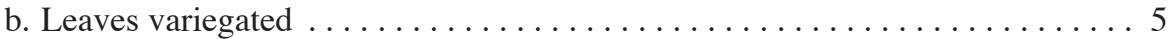

4a. Corolla tube pubescent outside; flowers yellow and white; labellum entire. $\ldots \ldots \ldots \ldots \ldots \ldots \ldots \ldots \ldots \ldots \ldots \ldots \ldots \ldots \ldots \ldots \ldots \ldots$ flavoalba

b. Corolla tube glabrous outside; flowers yellow and white, red at throat; labellum

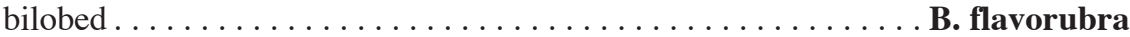

5a. Petioles to $0.5 \mathrm{~cm}$; lamina $4-8$ by $1.5-2 \mathrm{~cm}$, mid green with a broad silver band on either side of the midrib on the upper surface $\ldots \ldots \ldots \ldots \ldots$. kerbyi

b. Petioles $2-3 \mathrm{~cm}$; lamina $7-12$ by $2.5-7 \mathrm{~cm}$, dark green with a band of lighter green up the midrib, variegation sometimes extending to the main lateral veins . . . . . . 
6a. Fertile shoots single-leaved, rarely bladeless or 2 - or 3-leaved . . . . . . 7

b. Fertile shoots with two or more leaves . . . . . . . . . . . . . 11

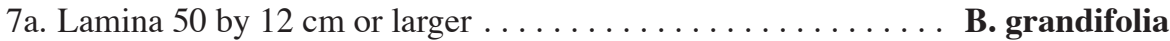

b. Lamina much smaller, not exceeding $30 \mathrm{~cm}$ long . . . . . . . . . . . 8

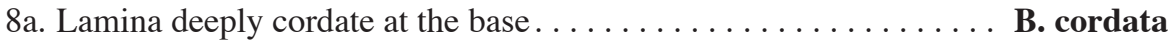

b. Base of the lamina more or less attenuate not cordate. . . . . . . . . . . . . 9

9a. Petiole $17-34 \mathrm{~cm}$ long . . . . . . . . . . . . . . . . . . . B. bruneiana

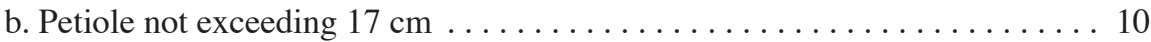

10a. Lamina 7-12 cm wide; petiole robust c. $5 \mathrm{~mm}$ thick; lamina with appressed hairs especially around midrib on the lower surface ......... B. lambirensis

b. Lamina less than $7 \mathrm{~cm}$ wide; petiole slender $2 \mathrm{~mm}$ or less thick; leaves glabrous

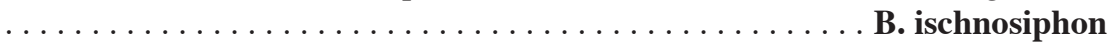

11a. Terminal leaf bases or sheaths broadened forming a bucket or vase-like structure enclosing inflorescence ....................... 12

b. Leaf base or sheaths not thickened as above . . . . . . . . . . . . . . 15

12a. Lamina small not exceeding $17 \mathrm{~cm}$ long . . . . . . . . . . . B. urceoligena

b. Lamina large, much longer than $30 \mathrm{~cm} \ldots \ldots \ldots \ldots \ldots \ldots \ldots$

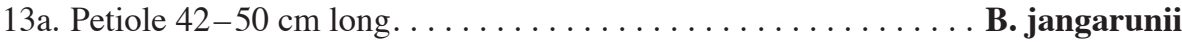

b. Leaf base long-attenuate forming a winged petiole less than $25 \mathrm{~cm}$ long . . . 14

14a. Inflorescence densely pubescent; anther c. $3 \mathrm{~mm}$ long, dehiscing by subapical

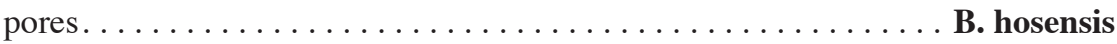

b. Plant almost glabrous; anther c. $10 \mathrm{~mm}$ long, dehiscing for c. $6 \mathrm{~mm}$ long (probably dehiscing by slits $\ldots \ldots \ldots \ldots \ldots \ldots \ldots \ldots \ldots \ldots \ldots \ldots \ldots \ldots \ldots$

15a. Leaves larger than 20 by $7 \mathrm{~cm}$; anthers dehiscing by pores $\ldots \ldots \ldots \ldots$

b. Leaves shorter than $20 \mathrm{~cm}$, if longer narrower than $7 \mathrm{~cm}$; anthers dehiscing by

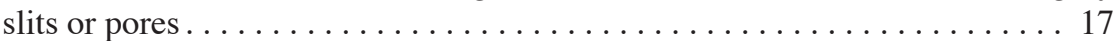

16a. Leaf sheath sparsely hairy or glabrous; bracts $5-8 \mathrm{~cm}$; corolla tube $8-10 \mathrm{~cm}$;

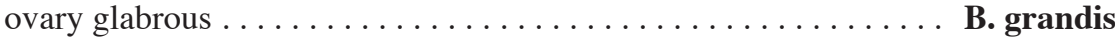

b. Leaf sheath densely hairy; bracts $2-3.5 \mathrm{~cm}$ long; corolla tube c. $5.5 \mathrm{~cm}$ long; ovary densely hairy on the upper half $\ldots \ldots \ldots \ldots \ldots \ldots$. lysichitoides

17a. Inflorescence long exserted from the leaf sheaths when fully grown, spindleshaped; flowers red and white $\ldots \ldots \ldots \ldots \ldots \ldots \ldots \ldots$. pulchella

b. Inflorescence never long exserted or spindle-shaped; flower colours various 18

18a. Leaves linear, arrangement of blades strongly flabellate . . . . . . . . . . . 19

b. Leaves elliptic, lanceolate or, rarely, linear-lanceolate, arrangement of blades never flabellate .............................. 20

19a. Flower plain yellow; anther dehiscing by apical pores; bracts $3.5-6.5 \mathrm{~cm} \ldots \ldots$ $\ldots \ldots \ldots \ldots \ldots \ldots \ldots \ldots \ldots \ldots \ldots \ldots \ldots \ldots \ldots \ldots$. flabellata

b. Flower white, yellow in the centre, pink at the base; anther dehiscing by slits; bracts up to $3 \mathrm{~cm} \ldots \ldots \ldots \ldots \ldots \ldots \ldots \ldots \ldots \ldots \ldots \ldots \ldots \ldots$ burttiana

20a. Leaves variegated (variegation may be lost in dried material in B. hirta); anthers

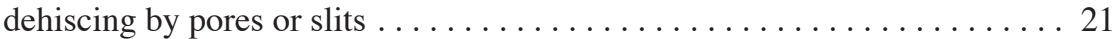

b. Leaves plain green; anthers dehiscing by pores $\ldots \ldots \ldots \ldots \ldots \ldots \ldots$

21a. Leaves bullate; dark green around main veins and almost silvery on raised area

B. hutchinsoniana

b. Leaves smooth with silver, yellowish or light green clouds centrally . . . . . 22 
22a. Petiole never exceeding $3 \mathrm{~cm}$; lamina oblanceolate with attenuate base $\mathbf{B}$. hirta

b. Petiole usually much longer than $3 \mathrm{~cm}$; lamina lanceolate to elliptic with cuneate

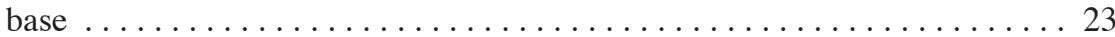

23a. Leaves with a silver cloud; flowers yellow, labellum orange spotted . B. ornata

b. Leaves with a yellowish cloud; flowers orange or white with some yellow and

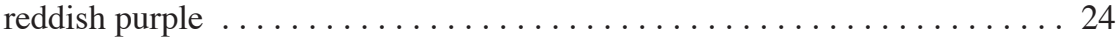

24a. Leaves $5-12$ by $3-5 \mathrm{~cm}$; flower orange, darker at base of labellum; anther dehiscing throughout the length . . . . . . . . . . . . . . aurantiaca

b. Leaves $18-23$ by $4-6 \mathrm{~cm}$; flower white with some yellow and reddish purple; anther dehiscing by apical pores, or anther dehiscent only the upper $2 / 3$. . $\ldots \ldots \ldots \ldots \ldots \ldots \ldots \ldots \ldots \ldots \ldots \ldots \ldots \ldots \ldots \ldots \ldots \ldots \ldots$ belalongensis

25a. Petiole up to $7 \mathrm{~mm}$; labellum yellow to orange . . . . . . . B. oligosperma

b. Petiole $1.5 \mathrm{~cm}$ or longer; labellum violet-brown with white bar or white with some

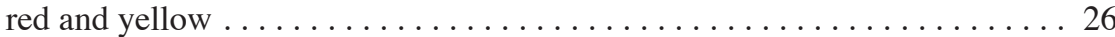

26a. Petiole usually $7-8 \mathrm{~cm}$ long; leaves narrow lanceolate $12-20$ by $1.5-3 \mathrm{~cm}$; a few flowers on an inflorescence ................. B. stenophylla

b. Petiole not exceeding $6 \mathrm{~cm}$; leaves shorter, if longer than $12 \mathrm{~cm}$ then wider than $4 \mathrm{~cm}$; many flowers on an inflorescence . . . . . . . . . . . . 27

27a. Leaves 13-16 cm long; labellum with white or yellow central bar bordered by

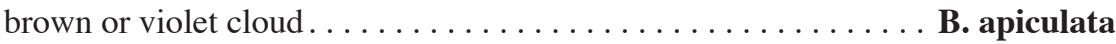

b. Leaves $12 \mathrm{~cm}$ or shorter; labellum white with yellow central bar and usually some red in throat $\ldots \ldots \ldots \ldots \ldots \ldots \ldots \ldots \ldots \ldots \ldots \ldots \ldots \ldots \ldots \ldots \ldots$

Excluded species: B. striata (Valeton) Loes. for insufficient information of the species; B. gracilipes as it belongs in Scaphochlamys (see below).

\section{GLOBBA L.}

\section{Globba brachyanthera K. Schum.}

Globba brachyanthera K. Schum. (1899) 329; (1904) 142; R.M. Sm. (1988) 15. - Type: Beccari 38 (FI), Sarawak, 1st Division, near Kuching, 06.1865.

Globba brachyanthera K. Schum. var. angustifolia Ridl. (1906) 232. - Type: Ridley s.n. (K), Sarawak, 1st Division, Mt Matang.

Globba affinis Rendle (1901) 176. - Syntypes: Hose 109 (E), Sarawak, 4th Division, Baram, Entoyut R, 11.1894, Hose 456 (n.v.), Baram, 25.10.1894.

\section{var. rubra R.M. Sm.}

Globba brachyanthera K. Schum. var. rubra R.M. Sm. (1988) 17. - Type: Burtt \& Woods 2363 (holo E; iso K, L n.v.), Lambir National Park, S of Miri, orange-red flowers [Bracts], petals and 'dancing girl' [lip and lateral staminodes] pale orange-yellow, stem red with green mottling, 05.07.1962.

Other specimens examined:

SARAWAK. Lambir Hills: Nagamasu 4695 (KYO), 08.08.1992; Momose \& Nagamasu 818 (KYO), 03.06.1993; Momose 722 (KYO), on lying wood, 30.06.1993; S. Sakai 43 (KYO), ht. 0.8 m, flower bud orange, fruits red, 19.06.1994; S. Sakai 165 (KYO), ht. 0.7 m, flower orange, fruit red, 07.02.1995. 


\section{HAPLOCHOREMA K. Schum.}

The genus Haplochorema was erected by K. Schumann based on the unilocular ovary with basally affixed ovules. However, this character is not diagnostic for the genus, because the ovary may also be trilocular or incompletely partitioned (Valeton, 1918; Smith, 1987), and it is now well-understood that the number of locules varies within Boesenbergia and other genera (Burtt \& Smith, 1964). In the current system the only character to distinguish Haplochorema from Boesenbergia is the labellum being deeply bilobed or emarginate, flatly held rather than saccate. Smith (1987) proposes to accept Haplochorema for the time being. After the replacements of Gastrochilus latilabrum $(=H$. latilabrum $)$ proposed below, the genus includes six species, five from Borneo and one from Sumatra, although identities of Bornean H. extensum and Sumatran H. sumatrana are uncertain.

Haplochorema latilabrum (Valeton) S. Sakai \& Nagam., comb. nov.

Basionym: Gastrochilus latilabrum Valeton (1918) 99. - Type: Nieuwenhuis 872 (BO), Kalimantan, Selebulan, Teputing.

Note - Valeton (1918) placed the species in Gastrochilus, because the ovary of the species is trilocular, which is not a diagnostic character of the genus any more. According to the label information on the type and original description by Valeton (1918) the flower is "Kaempferia-like" with a deeply bilobed labellum and a broad, recurved anther crest, but it is difficult to confirm this examining the poorly preserved flowers on the type.

\section{SCAPHOCHLAMYS Baker}

The genus is distinguished from allied Bornean genera (Boesenbergia, Kaempferia, and Haplochorema) (Smith, 1987) by having flowers in cincinni and short, free, basal spurs on the thecae.

Scaphochlamys gracilipes (K. Schum.) S. Sakai \& Nagam., comb. nov. - Fig. 7a

Basionym: Haplochorema gracilipes K. Schum. (1899) 332; (1904) 90. - Boesenbergia gracilipes (K. Schum.) R.M. Sm. (1982) 43; (1987) 221. - Type: Beccari 2839 (FI, K, P), Sarawak, 1st Division, G. Wah, 11.1866.

Notes - This species, originally described under Haplochorema, was moved to Boesenbergia by Smith (1982). She saw a specimen from Mulu (Burtt 8281, E) with reproductive characters of Boesenbergia, and she thought the specimen and the type material of $H$. gracilipes at the Herbarium of the Royal Botanic Gardens Kew were identical, failing to notice a small inflorescence under the tag. A well-developed and clearly visible lax inflorescence with flowers in cincinni, as noted in the description by Schumann (1904), and spiral arrangement of bracts found in the material at the Herbarium of Museo di Storia Naturale dell'Università, Firenze (FI) (Fig. 7a), further indicates that the species belongs to Scaphochlamys, which was misunderstood and 

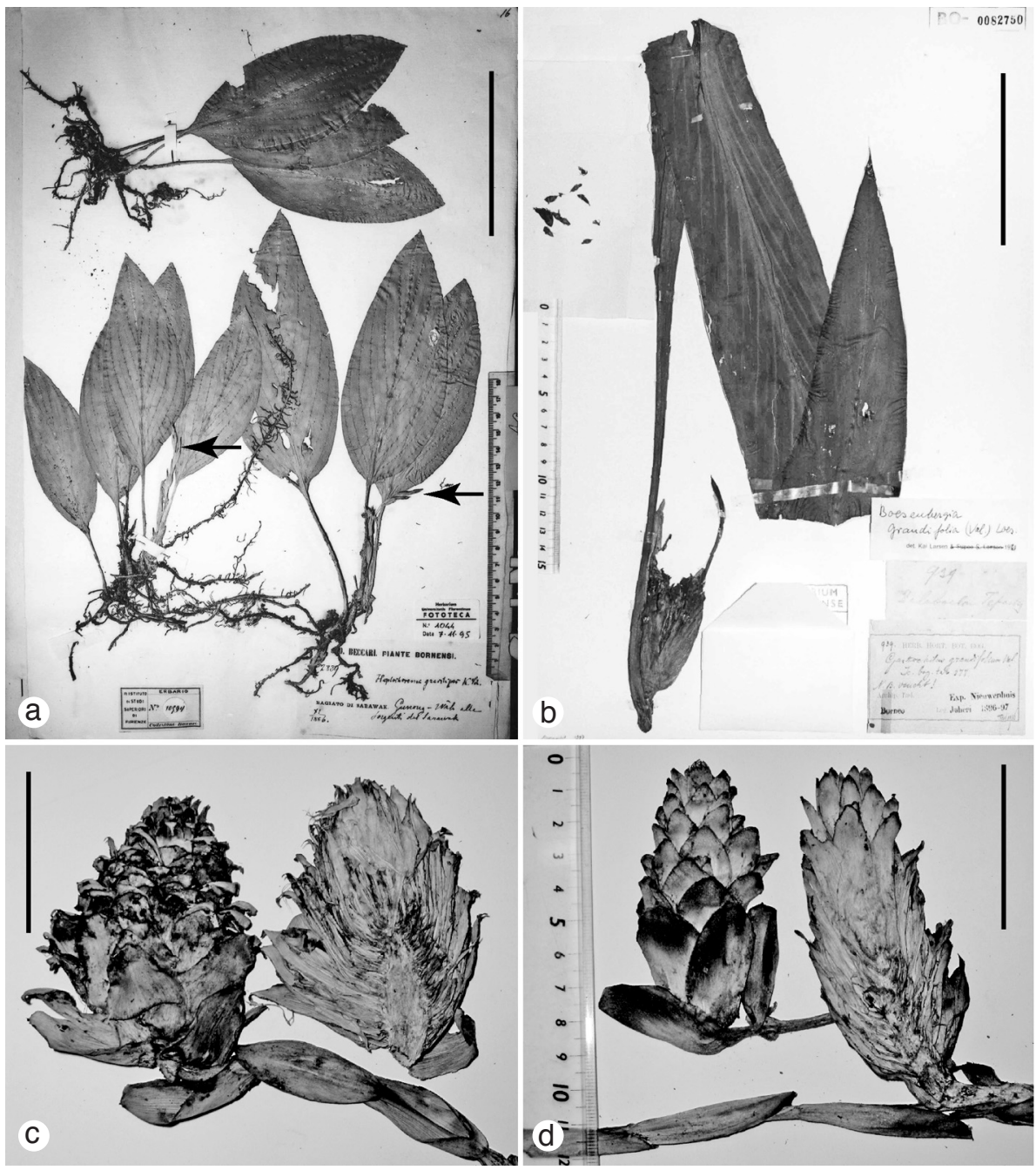

Fig. 7. a. Type of Haplochorema gracilipes K. Schum. (= Scaphochlamys gracilipes (K. Schum.) S. Sakai \& Nagam.), long and lax inflorescences are indicated by arrows. - b. Lectotype of Gastrochilus grandifolius Valeton (= Boesenbergia grandifolia (Valeton) Merr.). - c. Inflorescences of Zingiber longipedunculatum Ridl. var. longipedunculatum, Bario, Sarawak. - d. Inflorescences of Zingiber longipedunculatum Ridl. var. lambirense S. Sakai \& Nagam., Lambir, Sarawak (a: Beccari 2839 (FI); b: Nieuwenhuis 939 (BO); c: S. Sakai 304 (KYO); d: S. Sakai 248 (KYO)). — Scale bars: $\mathrm{a}, \mathrm{b}=10 \mathrm{~cm} ; \mathrm{c}, \mathrm{d}=5 \mathrm{~cm}$.

not accepted by Schumann $(1899,1904)$ (Smith, 1987). Most specimens identified to be $B$. gracilipes by Smith (1988) probably belong to Boesenbergia.

The lax inflorescence of $S$. gracilipes indicates affinity with $S$. polyphylla among Bornean Scaphochlamys, but the former is different from the latter in the more delicate inflorescences and single-leaved fertile shoots. 


\section{ZINGIBER Mill.}

After Smith (1988) revised the Bornean Zingiber including 16 species, 14 species have been described by Theilade \& Mood (1997a, b, 1999) and Theilade \& Christensen (1998). It is difficult to update the key provided by Smith (1988) without embarking on a proper revision of the genus.

\section{Zingiber longipedunculatum Ridl.}

Zingiber longipedunculatum Ridl. (1908) 149; R.M. Sm. (1989) 415. - Type: Hewitt s.n. (K), Sarawak, without precise locality, 1907.

var. lambirense S. Sakai \& Nagam., var. nov. — Fig. 7d

A typo bracteis utrinque pubescentibus et apice non reflexis differt. - Typus: S. Sakai 248 (holo KYO; iso SAR), Sarawak, Lambir Hills, swamp, near R. Aji, flower white, 14.06.1995.

Perennial herb 1-1.5 m tall, up to 21 leaves per shoot. Lamina up to 27 by $6.5 \mathrm{~cm}$, oblong to lanceolate, apex acuminate to $1.5 \mathrm{~cm}$, base cuneate, glabrous above, sparsely hairy below; petiole short to $5 \mathrm{~mm}$ long, pubescent; ligule to $3 \mathrm{~mm}$ long, shallowly 2-lobed, more or less hairy, margin thinner, sometimes ciliate; sheath sparsely hairy to glabrous but with somewhat dense hairs below ligules near the margin, margin otherwise membranous. Inflorescence radical, c. $5.5-10$ by $2.5-4.5 \mathrm{~cm}$, ovoid, with a peduncle of up to $40 \mathrm{~cm}$, prostrate on the ground, peduncular scales to $6 \mathrm{~cm}$ long, tubular at the base up to $1.2 \mathrm{~cm}$, pubescent on both surfaces, hairs are more sparse on inner surface; bracts up to 4 by $1.8 \mathrm{~cm}$ at the base of inflorescence, oblong, hairy on both surfaces, denser at the base of the outer surface, lower margin membranous, apical margin densely ciliate especially when young, apex obtuse and occasionally very shortly acuminate and ciliate, not reflexed when alive, although rarely slightly open outwards when dried (Fig. 7d); bracteole c. 26 by $7 \mathrm{~mm}$, oblong, open to the base, pubescent outside, glabrous inside except ciliate apex. Flower borne singly, white; calyx c. $22 \mathrm{~mm}$ long, tubular, unilaterally fissured in the upper half, pubescent outside in the lower $5 \mathrm{~mm}$, otherwise glabrous, apex acute or 2-lobed for $3 \mathrm{~mm}$, minutely ciliate; corolla tube $35-40 \mathrm{~mm}$ long, glabrous outside, hairy at the throat inside; corolla lobes glabrous, laterals c. 26 by $4.5 \mathrm{~mm}$, linear, connate to the labellum and each other for basal c. $8 \mathrm{~mm}$, dorsal c. 25 by $10 \mathrm{~mm}$, lanceolate; labellum c. 20 by $17.5 \mathrm{~mm}, 3$-lobed, central lobe c. 15 by $10 \mathrm{~mm}$, ovate, shallowly 2-lobed at the apex, side lobes 4 by $3 \mathrm{~mm}$, oblong and entire, glabrous; anther with c. $1 \mathrm{~mm}$ long filament, thecae c. $12 \mathrm{~mm}$ long, $2.5 \mathrm{~mm}$ wide each, glabrous, dehiscing throughout their length, anther crest c. $8 \mathrm{~mm}$ long, triangular, enfolding the style; style c. $6 \mathrm{~cm}$ long, glabrous, stigma c. $0.7 \mathrm{~mm}$ wide, cup-shaped fringed by long hairs, placed slightly higher than the tip of the anther crest; ovary c. 4 $\mathrm{mm}$, hairy; epigynous glands c. $7 \mathrm{~mm}$, linear, 2-lobed. Capsules unknown.

Distribution - Borneo, Sarawak, Lambir Hills.

Habitat \& Ecology - The species is often found abundant in swampy secondary forests. Bright red inflorescences are very conspicuous on the forest floor. The white flowers open around noon and are frequently visited by medium-sized Amegilla bees collecting pollen (Sakai et al., 1999). 
Note - Zingiber longipedunculatum is a species characterized by the long, prostrate peduncle and strongly reflexed bracts, which can easily be recognized in herbarium sheets, although size and shape of inflorescences and bracts vary significantly. In the type and most herbarium collections examined from Borneo, the inner surface of the bract is glabrous. Plants from Lambir Hills have rather flat, not reflexed, bracts, pubescent on both surfaces, and deviate from other materials.

Other specimens examined:

SARAWAK. Lambir Hills: S. Sakai 48 (KYO), secondary forest, ht. 1.5 m, 20.07.1994; S. Sakai 67 (KYO), secondary forest, bracts red, 05.08.1994; Yamauti 344 (KYO), mixed dipterocarp forest, 17.05.1996.

\section{Zingiber chlorobracteatum Mood \& Theilade}

Zingiber chlorobracteatum Mood \& Theilade described in Theilade \& Mood (1999) 514. - Type: Mood 342 (holo C), Sabah, Crocker Range, Kallang, primary forest, $550 \mathrm{~m}$ alt., across stream at upper falls, 30.08.1991.

Notes - We tentatively identified the collection mentioned below to Z. chlorobracteatum, although the Lambir material deviates from the type and original description of $Z$. chlorobracteatum by having a winged petiole of $1-2 \mathrm{~cm}$, and a much shorter height (1 $\mathrm{m}$ in the Lambir plant, $1.8-2.5 \mathrm{~m} \mathrm{Z}$. chlorobracteatum). Interestingly, the flowers of $Z$. chlorobracteatum do not open fully; a phenomenon also known from $Z$. viridiflavum, also in Borneo (Theilade \& Mood, 1999).

Although the winged petiole of the Lambir collection bears resemblance to Z. martinii, the type of the latter differs by being less pubescent on the leaves, especially at the base of the petiole, and outer surface of bracts and corolla tube. In addition, judging from fig. 2 in Smith (1988), the flowers open fully and the labellum is much larger (c. 3.3 by $2.3 \mathrm{~cm}$ versus c. 1.6 by $1.7 \mathrm{~cm}$ ).

Other specimen examined:

SARAWAK. Lambir Hills: S. Sakai 296 (KYO), near Canopy Biology Plot, flower yellow, 7.10.1996.

\section{Zingiber pachysiphon Burtt \& R.M. Sm.}

Zingiber pachysiphon Burtt \& R.M. Sm. (1969) 154; R.M. Sm. (1989) 412. - Type: Burtt \& Martin 4781 (holo E), Sarawak, 3rd Division, Hose Mts, below Bukit Mabong, 450-550m, on top of rock in forest, flowers cream, bracts dull light purple, 03.08.1967.

Other specimen examined:

SARAWAK. Lambir Hills: Burtt 11572 (E), leaves rather close with strong pulvinus, bracts vivid red, the recurved tip white, flowers pale cream, 21.09.1975.

\section{Zingiber odoriferum Blume}

Zingiber odoriferum Blume (1827) 44; Miq. (1859) 594; K. Schum. (1904) 178; Valeton (1904a) 12; (1904b) 257; (1918) 143. - Type: Kuhl \& Van Hasselt s.n. (L n.v.), Java, humid mountain near Tjihan javor, local name 'dongtrak' or 'tongtak monjet'.

Zingiber aquosum Blume (1827) 43; Miq. (1859) 594; K. Schum. (1899) 267; (1904) 179. - Type: Van Hasselt s.n. (L), Java, wetland near Sewerbong, flowering in September, local name 'belakatoa'.

Zingiber pachystachys Valeton (1918) 147. - Type: S.H. Koorders s.n. (BO n.v.), Java. 


\section{var. borneense Valeton}

Zingiber odoriferum Blume var. borneense Valeton (1918) 144, as 'borneensis'; R.M. Sm. (1988) 422.

- Type: Teuscher s.n. (n.v.), Borneo, locality unknown, cult. Bogor.

Notes - We have not seen the types of Z. odoriferum or the variety. Valeton (1918) described the arachnoid indumentum on the lower surface of the leaves, although it could be variable, and the fusiform spike of c. $20 \mathrm{~cm}$ supported by a 40-100 cm long peduncle. These characters more or less agree with the Lambir material.

The species was described by Blume on the basis of collections from Java, and Valeton recognized four varieties, three from Java and one from Borneo. Valeton noted that the Bornean variety differed in the more narrow, acute inflorescence.

Other specimens examined:

SARAWAK. Lambir Hills: Burtt 11663 (E), Sungai Lian Libau, c. 600 ft., shaded stream gulley, bracts red, frond 4-5 ft, compressed axis, 29.09.1978; Momose 5274 (KYO), 17.08.1996.

\section{ACKNOWLEDGEMENTS}

We are grateful to Prof. T. Inoue, Kyoto University, Prof. T. Nakashizuka, Research Institute for Humanity and Nature, Mr. Abang A. Hamid, Ms. Lucy Chong, Mr. Stephen Teo and other staff of the Forest Department Sarawak for permission and help during the study; Dr. Ida Theilade and Dr. Rosalind Searle for sharing knowledge of the groups discussed in the paper. Thanks are also due to the curators of the herbaria AAU, BO, BRUN, C, E, FI, HYO, K, L, OSA, P, SAR, and SING who kindly permitted us to examine and use photographs of herbarium specimens. This study is partly supported by grants from the Japanese Ministry of Culture, Sports, Science and Technology (\#14540643 and \#16405006), Project of the Research Institute for Humanity and Nature (P2-2), and the Grant for the Biodiversity Research of the 21st Century COE (A14), Japan.

\section{REFERENCES}

Blume, C.L. 1827. Enumeratio Plantarum Javae. Van Leeuwen, Leiden.

Burtt, B.L. \& R.M. Smith. 1964. A new species of Zingiberaceae from Sarawak. Trans. \& Proc. Bot. Soc. Edinburgh 39: 502-511.

Burtt, B.L. \& R. M. Smith.1969. Sarawak plants I. Notes Roy. Bot. Gard. Edinburgh 29: 141-155.

Cowley, J. 1998. Two new species of Boesenbergia (Zingiberaceae) from Brunei Darussalam. Kew Bull. 53: 623-629.

Holttum, R.E. 1950. The Zingiberaceae of the Malay Peninsula. Gard. Bull. Singapore 13: 1-249.

Kress, W.J., L.M. Prince \& K.J. Williams. 2002. The phylogeny and classification of the gingers (Zingiberaceae): evidence from molecular data. Amer. J. Bot. 89: 1682-1696.

Merrill, E.D. 1921. A bibliographic enumeration of Bornean plants. J. Straits Branch Roy. Asiat. Soc., Special number: 1-637.

Miquel, F.A.W. 1859. Flora van Nederlandsch Indië, vol. 3. Van der Post, Amsterdam

Pfeiffer, M., J. Nais \& K.E. Linsenmair. 2004. Myrmecochory in the Zingiberaceae: seed removal of

Globba franciscii and G. propinqua by ants (Hymenoptera, Formicidae) in rain forests on Borneo. J. Trop. Ecol. 20: 705-708.

Poulsen, A.D. 1993. Two new species of Boesenbergia (Zingiberaceae) from Borneo. Nordic J. Bot. 13: $289-294$.

Rendle, A.B. 1901. Mr. Charles Hose's Bornean monocotyledons. J. Bot. 39: 173-179.

Ridley, H.N. 1905. New and little known Malayan Plants. J. Straits Branch Roy. Asiat. Soc. 44: 189-211.

Ridley, H.N. 1906. Scitamineae of Borneo. J. Straits Branch Roy. Asiat. Soc. 46: 229-246.

Ridley, H.N. 1908. New or rare Malayan plants. J. Straits Branch Roy. Asiat. Soc. 50: 111-152. 
Ridley, H.N. 1909. New or rare Malayan plants. Series V. J. Straits Branch Roy. Asiat. Soc. 54: $1-61$.

Sakai, S. 2000. Reproductive phenology of gingers in a lowland mixed dipterocarp forest in Borneo. J. Trop. Ecol. 16: 337-354.

Sakai, S., M. Kato \& T. Inoue. 1999. Three pollination guilds and variation in floral characteristics of Bornean gingers (Zingiberaceae and Costaceae). Amer. J. Bot. 86: 646-658.

Sakai, S. \& H. Nagamasu. 1998. Systematic studies of Bornean Zingiberaceae I. Amomum in Lambir Hills, Sarawak. Edinburgh J. Bot. 55: 45-65.

Sakai, S. \& H. Nagamasu. 2003. Systematic studies of Bornean Zingiberaceae IV. Alpinioideae of Lambir Hills, Sarawak (excl. Amomum). Edinburgh J. Bot. 60: 181-216.

Sakai, S. \& H. Nagamasu. In press. Notes on inflorescence structure of Boesenbergia (Zingiberaceae). Acta Phytotax. Geobot. 57.

Schumann, K. 1899. Monographie der Zingiberaceae von Malaisien und Papuasien. Pflanzenr. (Engler) Syst. 27: 259-350.

Schumann, K. 1904. Zingiberaceae. In: H.G.A. Engler, Das Pflanzenreich IV.46. Engelmann, Leipzig.

Smith, R.M. 1982. Systematic notes on, and new species of, Zingiberaceae of the Gunung Mulu National Park. Bot. J. Linn. Soc. 85: 36-73.

Smith, R.M. 1987. A review of Bornean Zingiberaceae: III (Hedychieae). Notes Roy. Bot. Gard. Edinburgh 43: 203-232.

Smith, R.M. 1988. A review of Bornean Zingiberaceae: IV (Globbeae). Notes Roy. Bot. Gard. Edinburgh 44: 1-19.

Smith, R.M. 1989. A review of Bornean Zingiberaceae: V (Zingiber). Notes Roy. Bot. Gard. Edinburgh 45: 409-423.

Theilade, I. \& H. Christensen. 1998. Zingiber kelabitianum (Zingiberaceae): a new species from Borneo. Edinburgh J. Bot. 55: 239-242.

Theilade, I. \& J. Mood. 1997a. Two new species of Zingiber (Zingiberaceae) from Sabah, Borneo. Sandakania 9: 21-26.

Theilade, I. \& J. Mood. 1997b. Five new species of Zingiber (Zingiberaceae) from Borneo. Nordic J. Bot. 17: 337-345.

Theilade, I. \& J. Mood. 1999. Six new species of Zingiber (Zingiberaceae) from Borneo. Nordic J. Bot. 19: 513-524.

Valeton, T. 1904a. Über neue und unvollständig bekannte Zingiberaceae aus West-Java und Buitenzorg. Bull. Inst. Bot. Buitenzorg 2: 1-99.

Valeton, T. 1904b. Icones Bogorienses 2.

Valeton, T. 1914. Icones Bogorienses 4.

Valeton, T. 1918. New notes on the Zingiberaceae of Java and Malaya. Bull. Jard. Bot. Buitenzorg II, 27: 1-167. 